\title{
Jung and the arts
}

Christian Gaillard ${ }^{*}$

Instead of leading to yet another "applied psychoanalysis", Jung's encounters with the arts were privileged occasions for him to revive, rework and renew his own thinking. We will see this by considering alongside him some of the works from Antiquity, the Oriental traditions, Western alchemy, the Christian arts, the modern era, and from contemporary creation which proved to be decisive in the successive developments of his understanding and practice of the relationship to the unconscious.

\section{A strange exchange between Freud and Jung}

On the $17^{\text {th }}$ June 1910 Jung received from Freud Leonardo da Vinci and a memory of his childhood, the founding book of a whole tradition of the psychoanalysis of art.

As you know, in this brilliant and audacious essay, Freud undertakes the analysis of the work of Leonardo da Vinci according to what the artist lived since the cradle there is the famous memory of the bird which flew right up to his cradle, and put its tail into the child's mouth. Freud also considers the young Leonardo's relationship with his father and mother, or rather his mothers. For his argument, you will recall, he also calls in passing on a whole collection of Egyptian, Greek and Roman, then Christian examples where strange bird stories also appear...

From there, Freud proceeds to an interpretation of the probable homosexuality of the artist, or at least his homo-erotism, to the innermost, intimate tension that he always lived between his scientific inventions and his artistic creations, and his constant tendency throughout his life to leave a great number of his works incomplete, unfinished.

Using these autobiographical and biographical details, and of course his psychoanalysis and notably his theory of sexuality, Freud analyses, in particular, the famous painting in the Louvre entitled Sainte Anne, the Virgin and Child which you can see here.

\footnotetext{
* Doctor of psychology, training analyst and former president of the French Society of Analytical Psychology, president of the International Association of Analytical Psychology and professor at the Ecole Nationale Supérieure des Beaux-Arts (National Academy of Fine Arts) in Paris, France, till 2007. christian.gaillard07@gmail.com
}

Pro-Posições, v. 21, n.2(62), maio/ago. 2010 


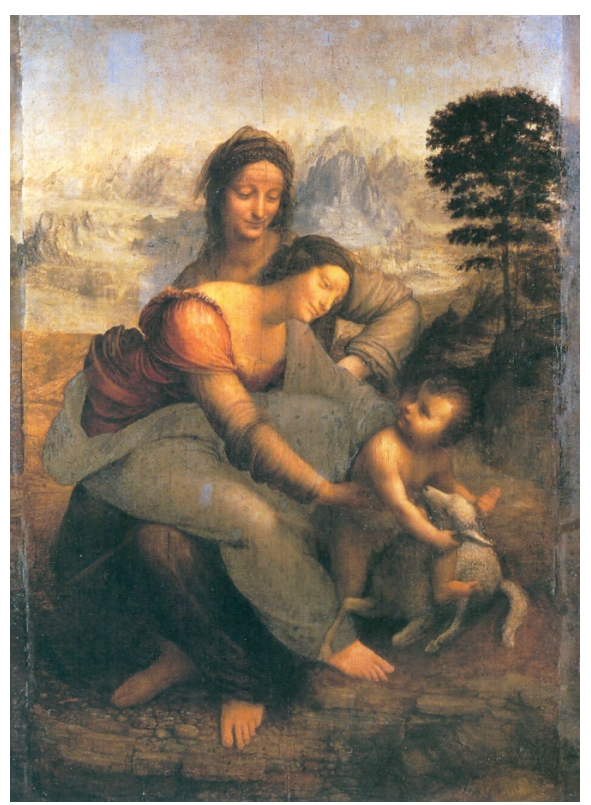

1. Ste Anne

In fact, this essay by Freud marks the beginning of one of the first orientations of research into the psychoanalysis of art, which ever since has also been the most revisited, and therefore the richest in publications to this day, and which we call psychobiography.

Psychobiography is the art and manner of explaining and analysing a work of art according to what the artist has lived in childhood, if possible since the cradle.

But do you know Jung's reaction to reading Freud's text?

His reaction was enthusiastic. Indeed he immediately wrote to Freud: "[Your] Leonardo is marvellous. I read it immediately cover to cover. [...] It is in fact the first of your writings with internal guidelines that I feel I can, in theory, identify with entirely" (Freud, Jung, Correspondance, II p. 65 en français)

Excellent, you will say. Isn't it pleasing, comforting, and heartening to see that our founding fathers, Freud on one side and Jung on the other, are in agreement on the same ground? And isn't it even more heartening because this common ground is the arts?

Let us be heartened, then. But not without looking a little closer at this story.

For Jung, in fact, does not stop there. He adds, still in his letter to Freud:

"The transition to mythology emerges from [your] writing with an internal necessity." Then he notes, rather as if he was addressing himself: "I would like to stay longer with these impressions, and follow up in peace the thoughts that will develop from here over a long time." 
So now here is Jung being thoughtful.

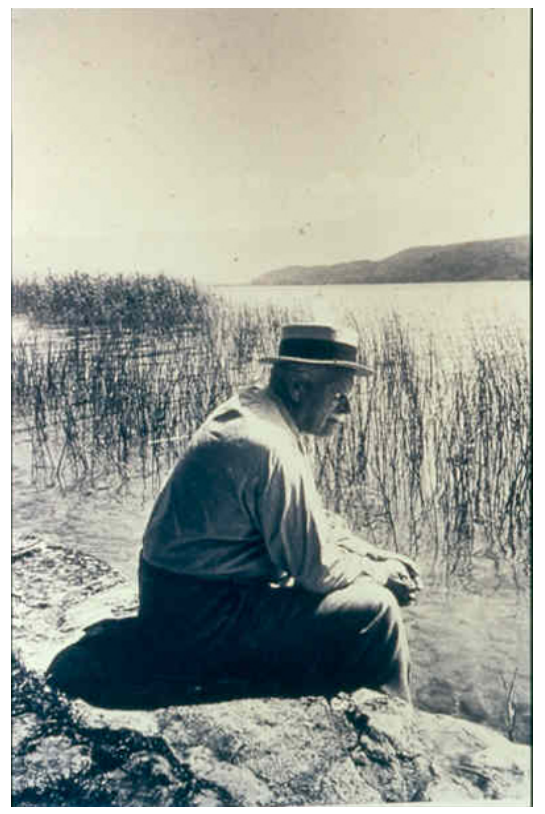

2. Au bord du lac

I like this photograph of Jung on the shore of the lake. I must admit that I didn't know of it before. It was recently brought over from Berne in Switzerland for me by one of my daughters - and I suppose that it touches me all the more because Jung here strangely resembles my grandfather.

(Psychoanalysis, I must add, is always a bit of a family business, with its filiations and heritage - and family business is always complex...)

All the same, Jung is quite thoughtful here. Or rather, I would say that he is letting himself think. He is letting as he says "the thoughts that will develop from here over a long time" rise up within him. Thoughts that manifestly must not be hurried; it is better for them to surface and emerge at their own rhythm. They want to take form, to find their own means of expression. But what are these thoughts?

I shall tell you straight away: we would have difficulty knowing that. Because Jung, curiously, never really explained his point of view either on his reading of Freud's essay, or on Leonardo's painting.

He only mentions it incidentally or indirectly in his work. But the position he takes when reading Freud's essay on Leonardo already tells us much about his psychoanalytical approach, and more specifically concerning the psychoanalysis of art. 


\section{Another approach at another scale}

Jung lets himself think. He will never practice what is called "applied psychoanalysis", psychoanalysis that applies what is already known to a work of art which in reality makes the psychoanalysis of art conceived and practiced in this manner not only an exercise that depends on current theory, but also an "unauthorised psychoanalysis", a psychoanalysis that lays the artist on the couch, without so much as asking his opinion, even in the artist's absence, in absentia as it were.

No, Jung's approach to the psychoanalysis of art is quite different. Instead of precipitating himself on the work armed with some established knowledge, he first marks a pause, as long as necessary, to let whatever comes to him internally when he discovers a work emerge. Indeed he has a word to describe this first stage in the analysis of a work, this first step in his method: he uses the double German verb "geschehen lassen" - in French "laisser advenir", in English "to let happen".

"To let happen", which also implies letting oneself be impressed, letting the work take its place in front of you and in you, making space for it, and then opening your perception and consciousness to the impressions, sensations and feelings that gradually come to the surface, or which impose themselves, as emotionally as possible, of course.

This is unfailingly surprising, and often captivating: astonishment, surprise, emotional captivation are in fact quite reliable indications that we are dealing with the unconscious, both in the psychoanalysis of art and in the practice of clinical psychoanalysis. I would go as far as to say that astonishment, surprise and emotional captivation are necessary conditions for engaging in a relationship with the unconscious, whether in a psychoanalyst's consulting room or in front of a work of art.

But, you might say, do we not risk getting lost or carried away in a wave of all too personal, all too singular associations, uncontrolled and pleased to project themselves onto the work in question? I often hear it said that a work of art is a good canvas for projection, so that anyone could use it as an opportunity to express what he or she is occupied or preoccupied by, and that, in consequence, all interpretations can only be subjective.

Evidently I do not hold this opinion. And neither does Jung. For the second verb that most often follows "geschehen lassen", "to let happen", in Jung's texts is "betracbten" which means "to observe, survey attentively and scrupulously".

Which is to say that if the Jungian approach to a work of art requires time to pause, and an aptitude to let oneself be impressed by that which then presents itself, then it is also methodically phenomenological. And this marks another divergence from the Freudian approach to art. The Jungian analyst hardly ever practises so-called "free" association.

The practice of "free association" does present the advantage of being open to the often unexpected flux of thoughts, sensations, feelings and intuitions which

Pro-Posições, v. 21, n.2(62), maio/ago. 2010 
follow their course within us. But it is precisely too "free" to really gauge what is in front of us, to accept the stumbling block that is an encounter with a work of art.

The Jungian approach, which observes as closely as possible that which we are dealing with, rather than deploying itself freely will concentrate on examining the work of art from divers angles, circumspecting it, in order to better recognise and appraise it. It is a circumambulatio as Jung would say.

And so how would we see the Saint Anne in the Louvre? We would see that it is inscribed, formally, or rather structurally, in an ensemble of representations, quite frequent in Germany and Italy at the time, between 1420 and 1520, these being representations of the Virgin, her mother and the Child which are called Metterze. Here is an example.

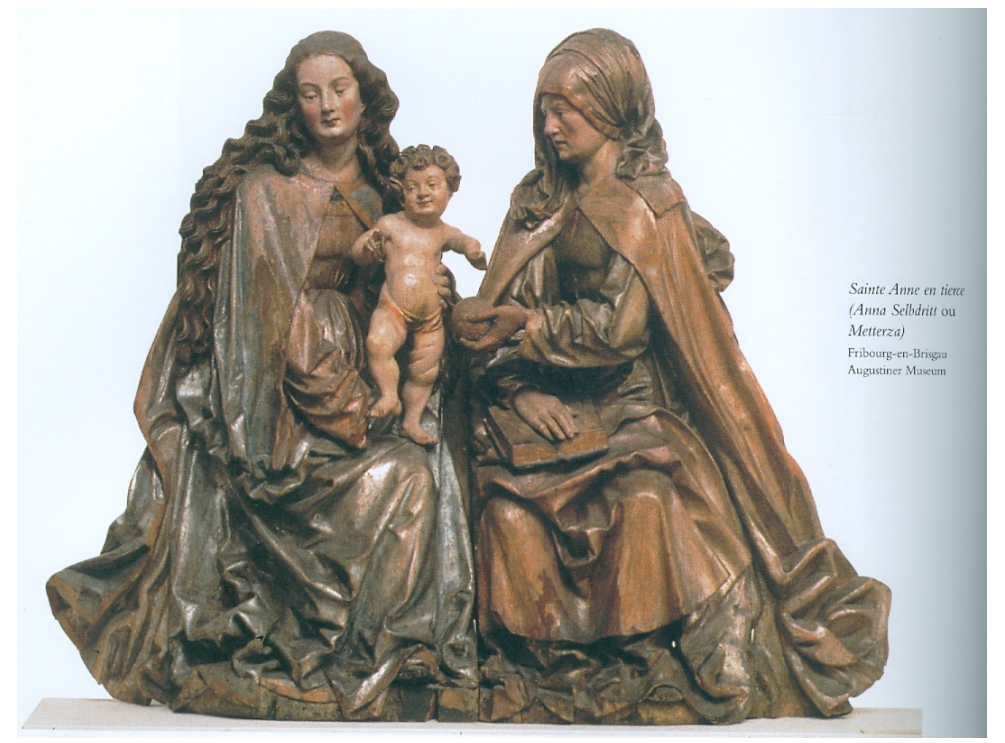

3. Metterza

Freud had of course noted this fact in his essay on Leonardo. But only in passing. He didn't dwell on it, being occupied by the almost causal exploration of the artist's childhood. To see the work, like Jung did, as a new event, but inscribed in a motif, a scheme, a pattern at once preexistent and in the making, is to practise an approach at once phenomenological and structural. Jungian psychoanalysis of art is a practice of surprise, and it is phenomenological and structural in that it renders us attentive to recurrence, as well as to the evolution and transformation of typical representations which come to us from afar, from the furthest parts of ourselves, and also attentive to the active archetypal backdrop to our collective history.

And the evident consequence is that this approach is decidedly un"psychobiographical". It observes, analyses and works at a different scale. At a transpersonal and in particular a transgenerational scale. Indeed, I shall go as far as to say 
that Art, in its forward movement at the level of our collective history, is more interesting and important to us than the artists, in the singularity of their lives...

\section{Janus?}

So as to see and express this better, let us come back to Jung, Jung in 1910. At this time, Jung had recently moved into his house at Küsnacht, near Zurich, a house that he had designed himself with his wife, and the building of which he had monitored closely.

Now what can we see, even today, on the lintel of the front door to this house?

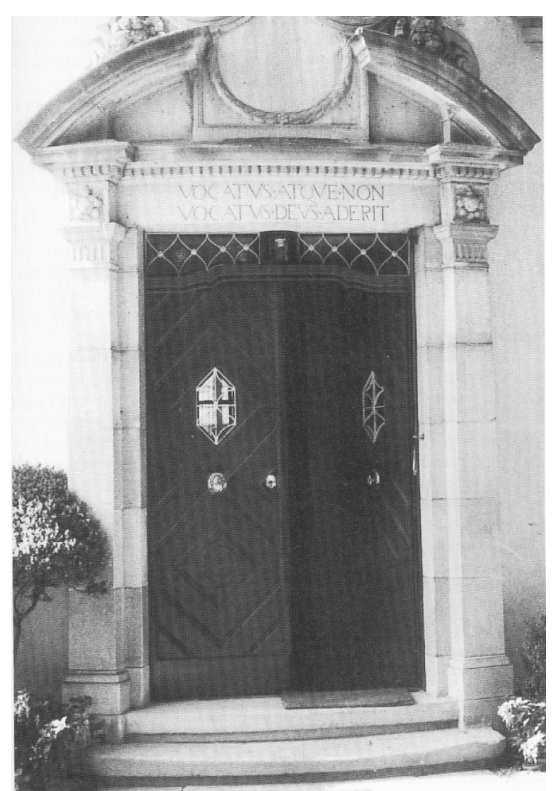

4. porte d'entrée de Küsnacht

We see this latin inscription : "VOCATUS ATQUE NON VOCATUS, DEUS ADERIT ». "Whether we invoke Him or not, God will be there."

I mentioned surprise earlier. And here's something surprising. We know that this phrase comes from the Humanist Erasmus of Rotterdam, and that Erasmus himself had found it at Delphi: this is one of the oracles - quite unexpected of course - of the goddess of Delphi.

These words, then, that Jung had carved in stone, and that welcome visitors, or impose themselves on them in a surprisingly appealing manner, come from a long time ago, from the furthest point of our collective history. 
But what is this announcement doing here, and what does it mean; this enigmatic announcement, or expectation, or fear of an encounter that we find at the heart of all living religions? What is it doing on a psychoanalyst's door?

Let us point out here the innermost, intimate kinship between the approach to the arts and the approach to religions in the Jungian tradition, which I have called phenomenological, and whose required emotional engagement I have emphasised. It is possible that the arts could lead us to encounters as captivating and demanding as religious experience can be.

But let us emphasise here Jung's constant position concerning what we call religion. For him, and he reiterates this often, the very term "religion" does not come from the Latin word "religare" which means "to link" or "to attach" as the Church Fathers would have it: for them it implies attaching oneself to God, of course.

Conversely, Jung takes this word "religion" in the sense that Cicero uses, for whom the word religio, "religion" does not come from religare, which means "to attach", but from re-ligere or re-legere, which means "to reread attentively, to observe, to consider, to reconsider and to think".

And in case we should forget this requirement of observation and thinking, which is at the heart of the Jungian approach which I have called phenomenological, Jung placed very visibly in his consulting room, which is also where he wrote, on a tall stove surrounded by books from his rich library, this work, this sculpture which can interest us:

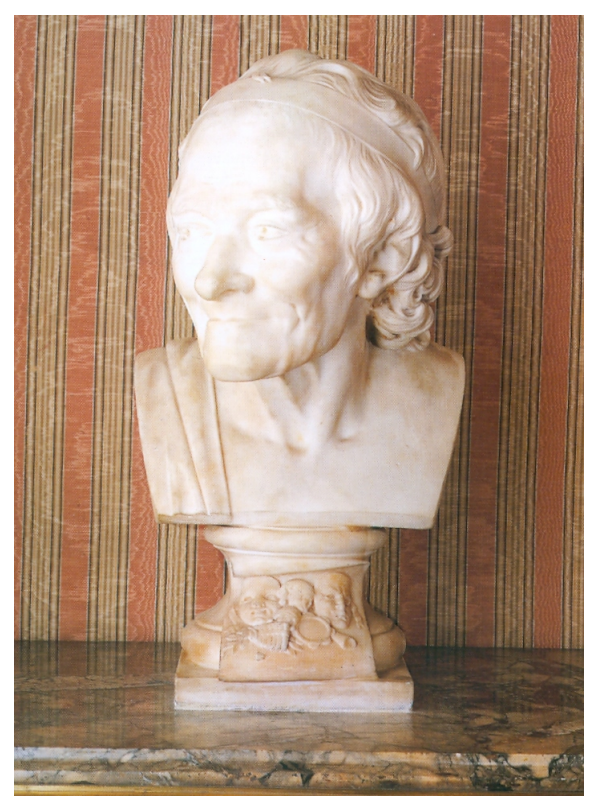

5. le Voltaire de Houdon 
It is evidently a copy of the work by the famous French sculptor Houdon. Jung had no doubt brought it back from Paris after his time as a student of Pierre Janet at the Collège de France.

This Voltaire has the eye of a scrutinizer, demanding and without mercy; this philosopher of the Enlightenment, without complacency for himself and for others, watches, follows, observes, scrutinizes and questions insistently, and manifestly not without irony. And he was present in Jung's consulting room, with the harsh ironic smile you can see, watching the visitors who came to consult their admired master, and at the same time accompanying Jung himself throughout his life, in his works and writings.

On one side the oracle of Delphi carved on the lintel of the front door, on the other, inside, the watching and smiling Voltaire: here we have quite concretely the encounter and interpellation that will always be at the heart of the Jungian approach to the arts, and to religions.

And we also se here, no less evidently, the art which speaks to us today can come from long ago and from many different regions of our collective history: from Greek Antiquity, via Erasmus, and from the French Enlightenment.

Finally, we can see more precisely, in methodical terms, that we must not only open ourselves to that which presents itself and make room for it, whether the encounter is expected or not, but we must also watch and observe vigilantly and demandingly. What is more, we must appraise ourselves, confront this encounter as directly and deliberately as possible: Jung adds another verb to the sequence I have already evoked, after geschehen lassen (to let happen) and betrachten (to observe), Jung often adds sich auseinandersetzen which means "to appraise oneself, to confront". This has all sorts of consequences for his analytical thought and practice, consequences which we must now consider.

\section{A bull in Rome}

Still in order to better show the approach Jung takes when grappling with the arts, let us take a few more steps into the story of Jung's life and work, which is also the story of his encounters with works of art from diverse eras and different parts of the world.

We are now in 1911. Just before Freud's Leonardo da Vinci and a memory of his childhood, Jung received another text from his colleague Dr. Flournoy in Geneva.

It contained two poems, in a half-tragic, half-playful style, and some travel thoughts which conjured up all sorts of Byronic sensations and emotions, all composed by a young American woman called Miss Miller, who is manifestly torn between the romantic encounter which she doesn't dare abandon herself to and the regressive nostalgia that attaches her to her mother and her satisfactions up until now. 
Jung did not know this young woman. And he did not seek to know any more about her, or in particular her childhood. Instead, he opened his mind and his pen to a whole impressive mass of myths, rites and narratives that he has found in the most diverse cultures, and which are thematically associated to the young woman's writings.

This is the starting point for his book Symbols of Transformation, a huge book, abundant and so rich in different documents that one could worry about losing oneself.

Jung, however, does not lose himself. Why? No doubt because at the heart of this book is one work, a sculpture, around which the whole collection of myths and rites associated with the young woman's writings is organised, which allows him to constantly return to and never lose sight of the crucial questions which occupy this Miss Miller. Here is that work:

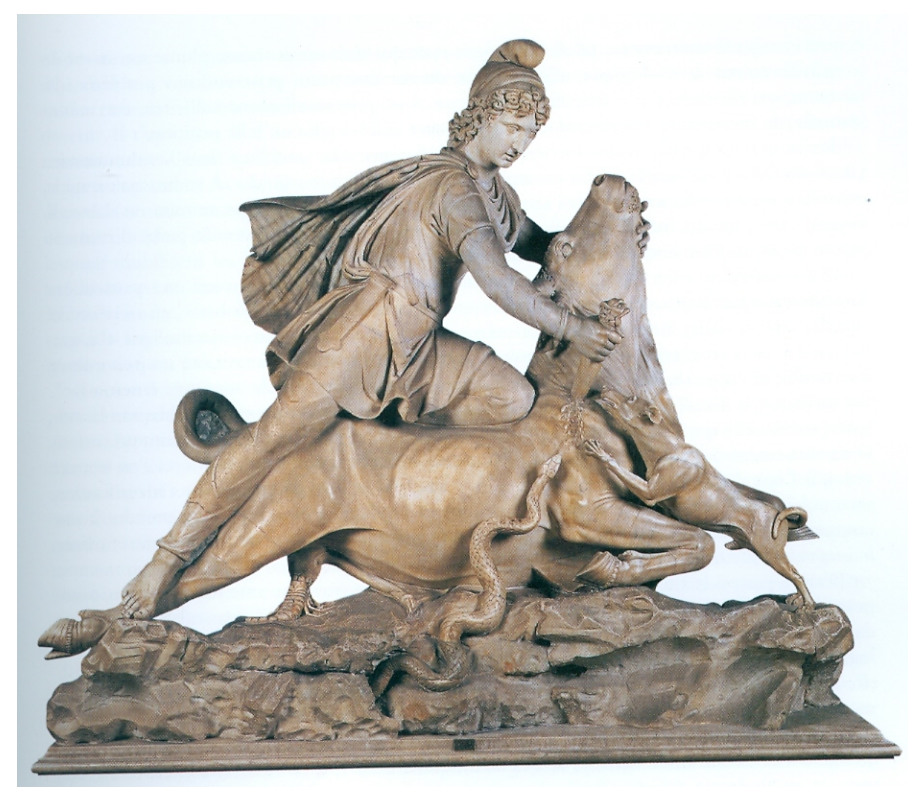

6. le sacrifice de Mithra

What does it portray? The sacrifice of a bull, the bull of Mithra. With a violent gesture, but at the same time within a tight hand to hand struggle, between the young hero and the bull in its live animality, a struggle actually manifestly intimate and powerfully refractory.

From this work, central to Roman art and life, Jung proceeds to question the Freudian theory of sexuality by showing that each of us, like this young Miss Miller, is struggling with an animality, with urges well prior to the Oedipus, well prior to the discovery of the difference between the sexes and the relationship between the sexes. 
He shows us, through the analysis of this work and others that are akin to it, that we live a tension and a struggle with a libido initially made up of undifferentiated urges, which both powerfully summon us and fascinate us, and with which we wrestle, and must also triumph over and control.

So his attention is displaced away from the Freudian question, centred on the Oedipus and the father, towards the differently regressive attraction of incest, and then to the crucial, imperious and painful necessity of sacrifice. His own thinking, and his own way as a clinician of working the relationship to the unconscious were provoked and nourished, and were given substance - here is a real occasion to say so - because of his encounter with this work, at first enigmatic to him, and with all those he discovers and analyses while writing this book.

In this manner he anticipates, in his own way, the later expansions of psychoanalytic thought, especially the work of Mélanie Klein on the violently archaic tensions of what she calls the schizo-paranoid position, and on the darker moments of the depressive position. But the arts, we see when reading Jung, had already shown us this.

In fact, as you will have understood, for Jung Art precedes us. And it makes us live that which otherwise often remains out of reach. It is for us to learn to recognise, think and work with what is portrayed, in a captivating but strangely enigmatic way.

\section{The work of the hands}

It remains for us to undertake boldly and personally this kind of relationship with the unconscious, with its own talent for expression, figuration and dramatisation.

Jung physically undertakes this at several crucial moments in his life, most especially after breaking with Freud, from 1913 to 1918. He gets his hands dirty, as it were. Not really knowing how or what to think, he engages with some difficulty in very hesitant games of construction, sculpture and modelling in his garden. You know that he also engages in drawing, painting and calligraphy. Without understanding anything at the beginning, of course. But he accepts. Because he sees and learns that these exercises give him rhythm, and a quasi-religious breathing, which gradually lend him calm and most importantly structure.

Here again he is before his time. For there was no hint yet of "art therapy". But that is exactly what he is experimenting at first for himself, and then with his patients. And it is to this that his later work with psychotics owes all its meaning, as does his recognition of the work done here in Brazil from the 1940s onwards, by the Doutora Nise da Silveira.

In one of his first truly Jungian writings, published in 1916, he was able to write: "Hands often know how to decipher an enigma that the intellect struggles with in vain." And from this point onwards a large part of his work as an analyst will consist in bringing together in one research movement the work of the hands and that of the 
mind; the work of giving form (in German he says Gestaltung), and of understanding (Verstehen).

Here are a few of his paintings from this period. They cannot be considered from an aesthetic point of view, of course, but for what they make us realise and live with regards to his relationship to his inner world and the world around him.

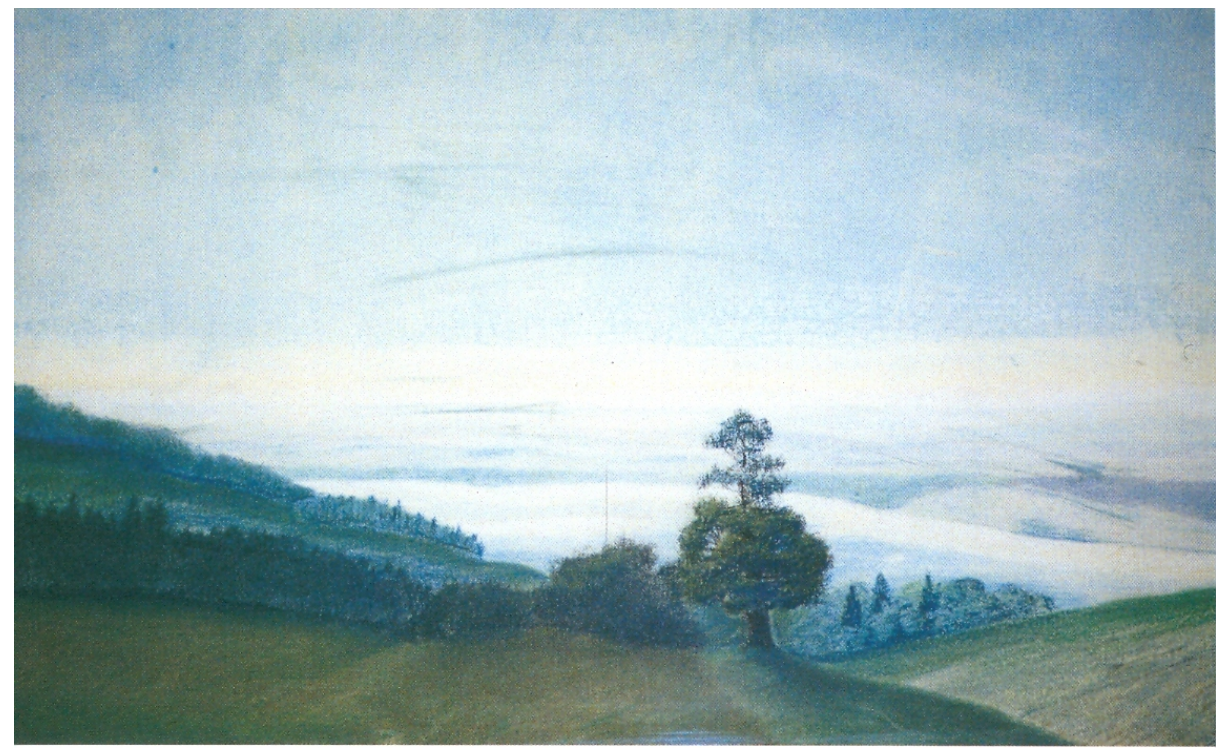

7. le lac de Constance

This is a lake, Lake Constance, near where he lived. The watercolour contains the landscape, becomes its melting pot, around which the tree organises the composition. Jung is as yet hardly acquainted with the Oriental arts, particularly Chinese art, and the mandalas of Mahayana Buddhism, that he will soon study closely. But here he experiments just that, as yet silently. 


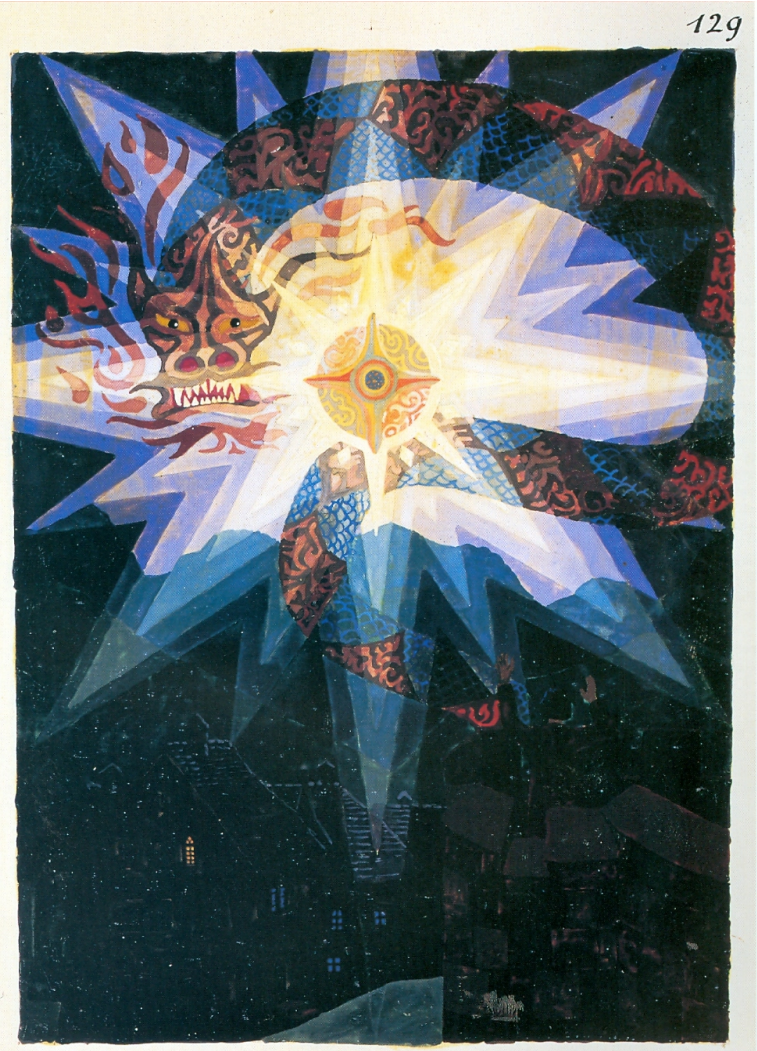

8. I'étoile et le dragon

This painting can be found in an unpublished book where he stored a whole section of his graphic production. It is a cosmic event. Like a super nova that is exploding, but remains centred. And a primitive animal, a snake-dragon, still distant from the human order, curls around the whole, and contains it. 


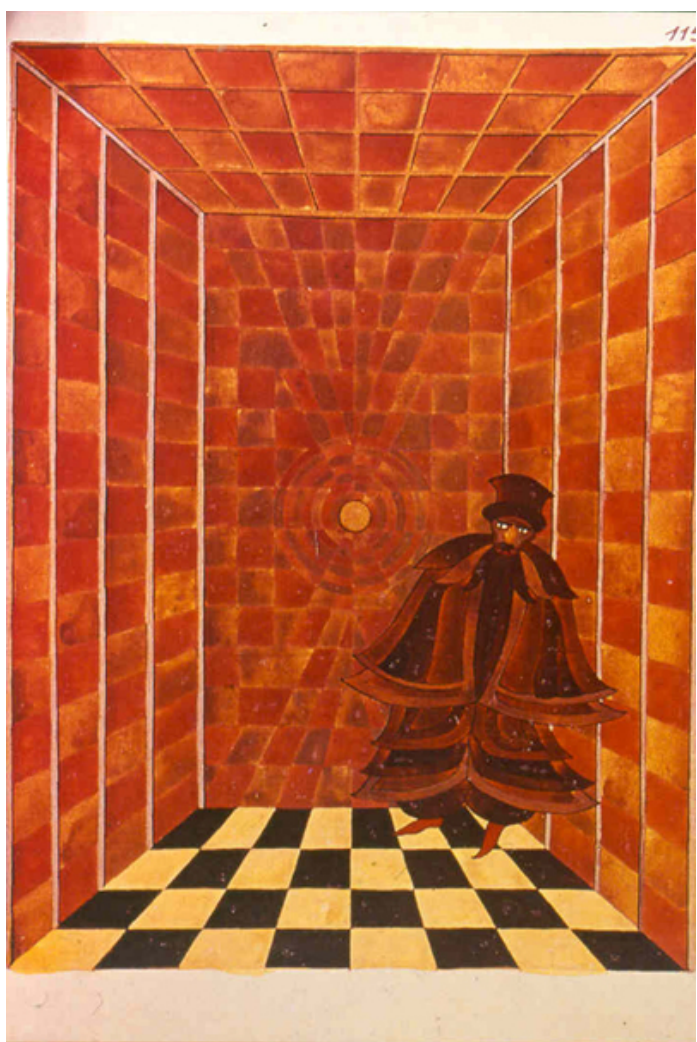

9. le « colporteur» (the hawke)

This scene is architecturally more closed in on itself. This prefigures the "inner scenes" that we will see later. A character appears. An ambiguous being, dark, and we don't really know whether he is promising or threatening. That is, there is a character who has his place here, and with whom perhaps one could make contact.

Jung analysed this type of character, which we can recognise quite frequently in the course of an analysis, in the rest of his works. He talks about the shadow that haunts each of us, and that represents what we don't want to know or recognise in ourselves, which we usually project onto others around us.

Here again, the encounter and the experience precede the conceptual thought. 


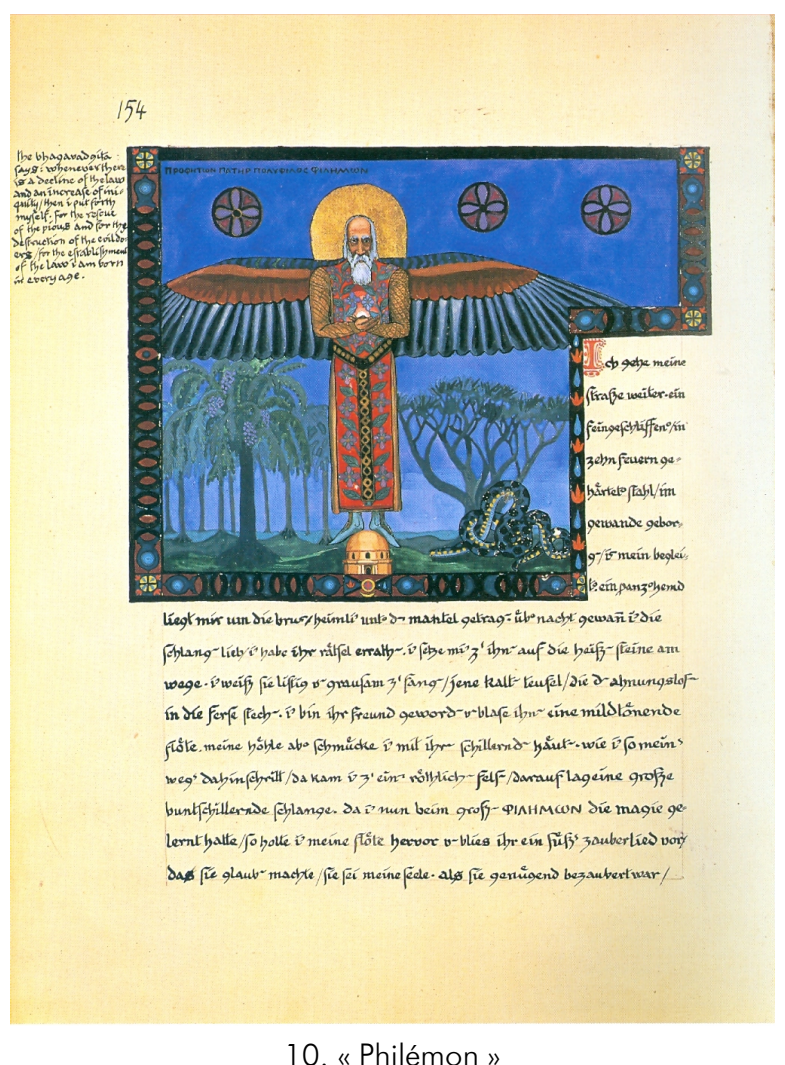

Over the years, another character took form. Jung gives it a name: he calls it "Philemon". It has a large bird's wings. And the snake is not far off. But Jung writes in his Autobiography how it became almost familiar company, with whom he could debate and even have arguments.

At the time of painting this page and writing the story that accompanies it, Jung has not yet conceived of and developed his theory of archetypes. But this tall hieratic figure, almost timeless, for Jung already represents, renders present, one of the states that he will later call the self, one of the states, initially unconscious, of the accomplished personality.

So we can see that, through the arts, a dialogue can form with the characters and presences of our inner world, of our "inner stage": his, mine, yours.

\section{A perfect temple in India}

This dialogue, in the 1920s and 30s, will take the form of a debate with the Oriental arts. Arts that attract and fascinate him, and that he will study closely, because he feels himself to be at once very close to them and yet in need of 
distancing himself. He will go to India, to see Hindu and Buddhist statues, painting and architecture close up.

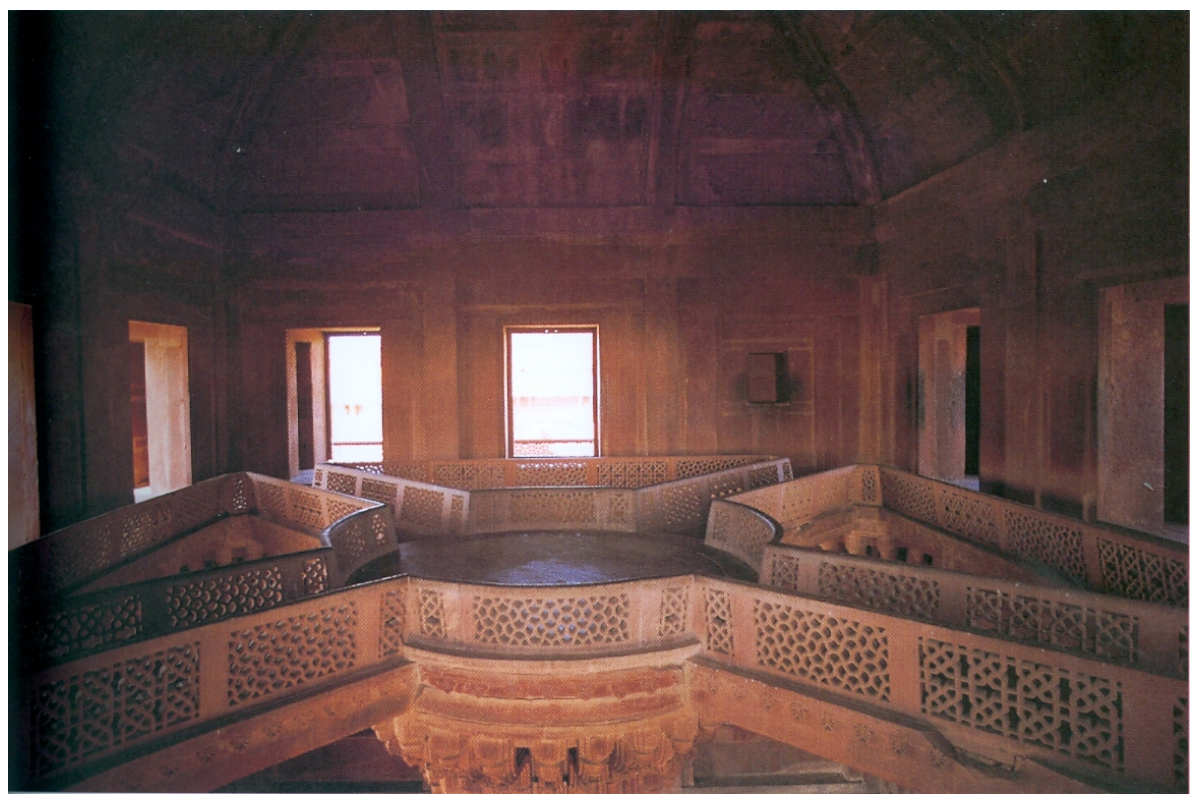

11. le Diwan-i-kaas, en haut

I had a lot of difficulty finding this photograph, which shows the Diwan-i-kaas, as Jung first saw it at Fathepur Sikri, and then in a dream that would be decisive for his work because it precedes the writing of one of his major books, Reply to Job.

Here we can see the top floor of this temple, which is both lay and religious.

The powerful ruler of these lands, the sultan Akbar, presided from the centre of the edifice, at the top of the tall central column, wisely surrounded by his ministers and councellors, and ruling people and things from here.

An almost perfect inner disposition, then, right up to the ideal harmony in his relationship to the world. While Jung was in India, he was powerfully impressed by this. But in fact, he evidently didn't really know why.

Here is another view of the same edifice. 


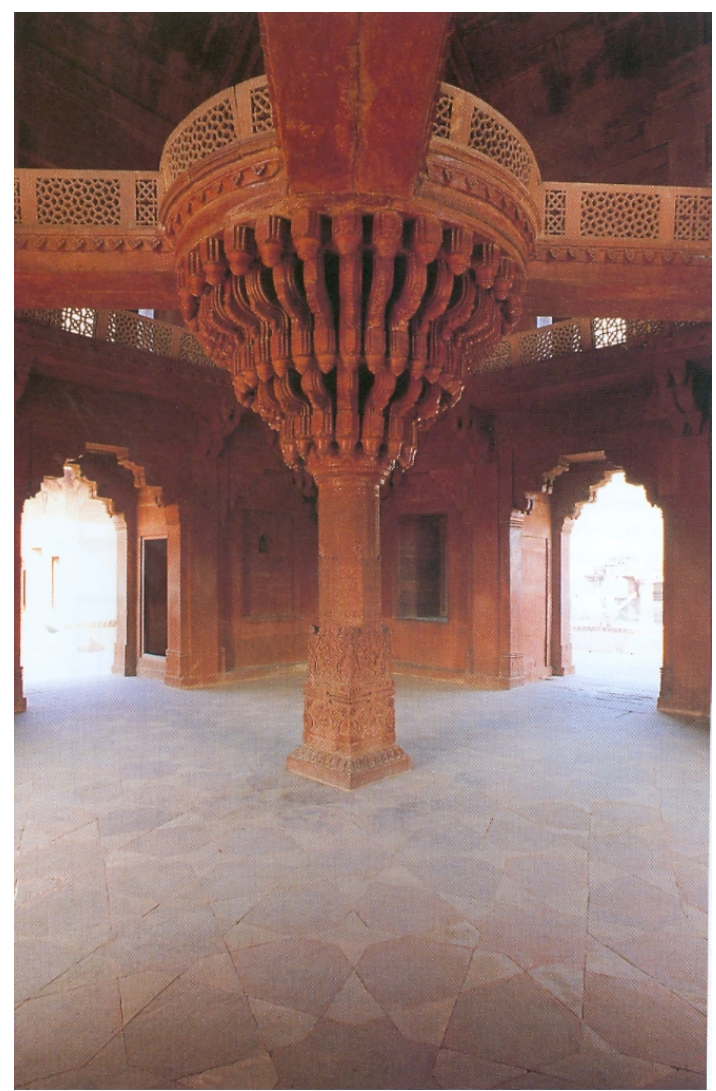

12. Le Diwan-i-kaas, d'en bas

I wanted to show you this other view of the Diwan-i-kaas, this time seen from below, because this is how it appeared in Jung's dream, where he found himself here, many years later.

In his dream he revisits this same edifice. But he sees it from below, as we do here. And he does not see Akbar the Great, the Oriental potentate who ruled Fathepur Sikri in India, but King David from the Biblical tradition, from our Bible.

The scene, the story is brought closer to us. Closer to our culture. And closer also to Jung's own personal story, and to one of his very first encounters with the arts, because the first painting that ever really caught his attention, and in front of which he stayed mute with admiration for hours on end, was a copy of a large painting by Guido Reni, the original of which is in the Louvre, and which represents, precisely, David, the young and handsome David of the Bible, victor over Goliath. Jung was then still a child, and this painting was in the family house, in the presbytery of his father, who was the pastor of a small town near Basle. 
In his dream, then, King David takes the place of the sultan Akbar. But the scene transforms again. Another event intervenes - as often happens in a dream. Jung sees and understands in this dream that higher than the king David, more admirable than him, there is another presence.

Who can it be? None other than the king's servant, the general Uriah, who the handsome, luminous, ideal king David had sent to die in combat so as to claim the wife of this faithful soldier for his own pleasure.

Jung, still in this dream, bows down, nearly to the ground - seeing the edifice as we see it here. He bows deeply, nearly to the ground, to salute and honour this wounded, sacrificed man, more honourable and venerable, and more worthy than the ideal king David himself.

First conclusion: no-one and nothing is perfect, it appears. One had better know that much.

What is more - second conclusion - Jung, still in this dream, as I have pointed it out in passing, does not bow right down to the ground. Despite how impressed he is, he keeps himself a margin, a space in which to observe, to think, and to analyse that which presents itself in front of him. And this margin is also his margin of liberty.

Faced with something that surpasses him, something that surpasses us, in huge disproportion, we must think. And we must take a stance. A stance at once critical and ethical.

For man, Jung writes, just as Job faced Yahwe, even in the disproportion where he manifestly finds himself facing that which he discovers and which can dangerously impress, fascinate or assail him, keeps his judgement, his capacity for consciousness, his power of analysis, and especially his power to take a stance and to act. That is his task, and that is his strength.

\section{The alchemists' laboratory and Christian culture}

As you know, Jung dedicated a whole part of his life and work to a critical evaluation of Christianity, of our Christian culture and its dearest ideals. And here again his discovery and his practice of the arts opened up and showed him the way forward.

From the mid 1930s, and for over two decades, he devoted himself to a passionate exploration and study of the iconography and literature of our Western alchemy.

One of the constant characteristics of the alchemists' work is that it is discreet, solitary, almost secretive, and that it is in any case developed outside, or rather beneath established theories and recognised dogmas.

It is also very practical, laboratory work, and at the same time an exercise in mediation and thinking. This is illustrated here, in a fifteenth century manuscript, 
where in the foreground two alchemists are busy round the ovens, while a third, who resembles traditional representations of Saint Jerome in his cell, devotes himself to the attentive and precise study of diverse symbolic objects, including a sun and a moon.

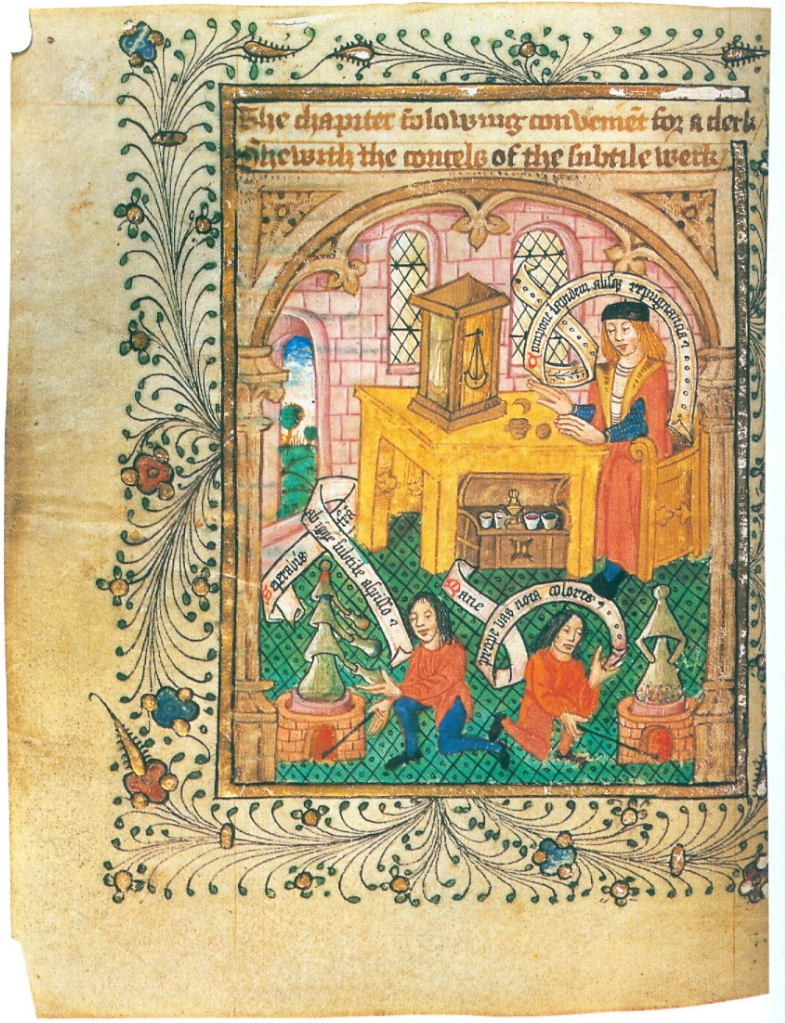

13. Ordinal de Norton

Jung felt at home here. He was one of the first of his time to closely study and procure for himself all sorts of alchemical manuals. These works, often widely illustrated, were at their time usually considered heretical. It is indeed true that they were often developed in clear opposition to the high truths defended and imposed by the then dominant Church. But Jung himself was always refractory against any form of orthodoxy, including Freudian orthodoxy.

At the time of Jung, these books were widely held to be truly grotesque and absurd. But right from his first psychiatric works Jung had lengthily explored, not without success, the apparently senseless enigmas of psychosis, and as we have seen 
he had learnt to let himself think with his hands, by working in clay or stone, or with a brush.

It remains that he must accept to lose, at least temporarily, his Latin, and accept that the beacons that had lit up the road thus far should go out. This is illustrated in a sixteenth century alchemical manual that Jung discovered in the 1930s.

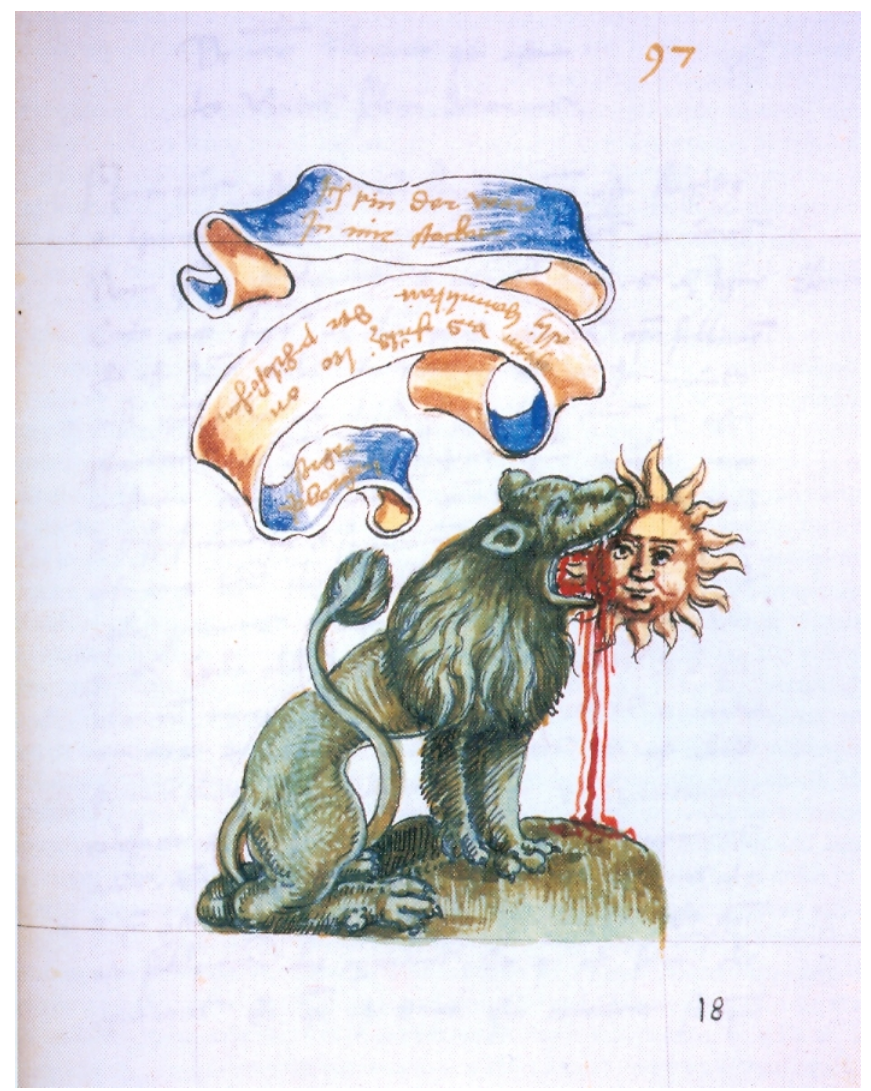

14. Le Lion dévorant le soleil

Here the sun is harshly attacked. Hurt and bleeding, the sun is caught in the jaws of the lion who is devouring it and will swallow it up. A nasty business. And Jung recognises it because he has lived it himself, of course. But most importantly it gives him the inspiration and the raw material necessary to analyse the cruel fate reserved for the ego and its lights when we truly undertake the evidently adventurous and largely regressive exploration of our backgrounds and backdrops, often written into the body's memory since early childhood, or from even further back, and often devilishly animal. 


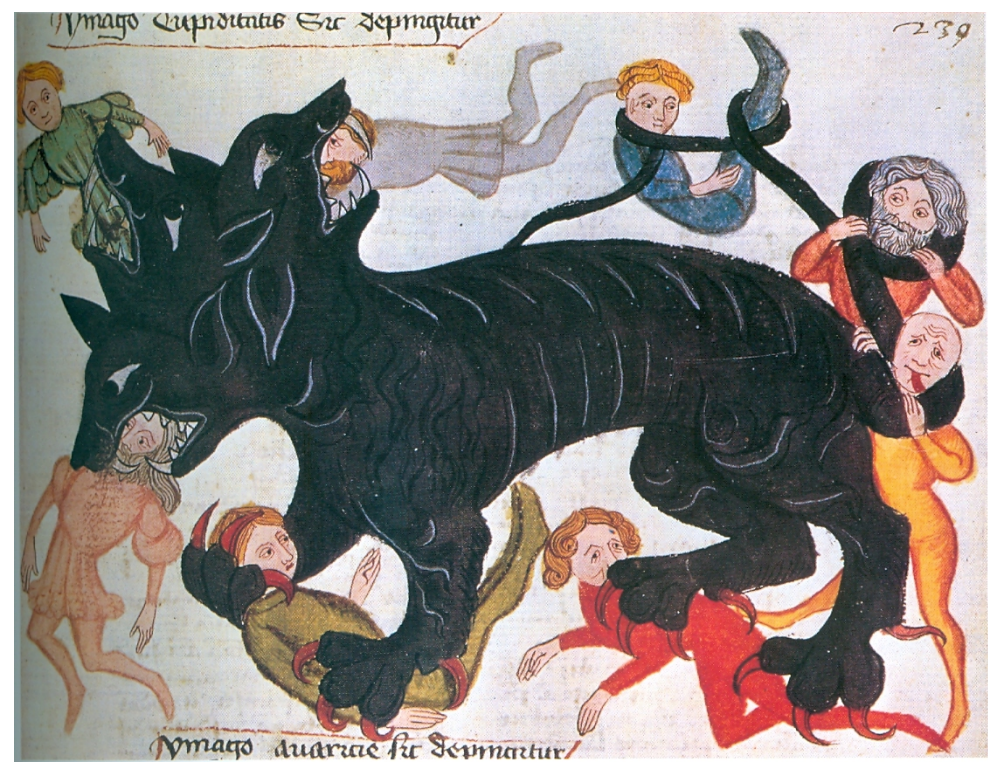

15. Chien-dragon dévorant] the devouring dog-dragon

This image takes us even further in the sense - and apparent nonsense - of such an adventure. The animality here seems even more devouring and lacerating. Here we must run for our lives. But in vain. This is Hell.

From here Jung can show that the ego is not only decidedly not the master of its own house, as Freud has already taught, but that in fact the experience of the live and most archaic forces of the unconscious is also an experience of the most elementary chaos, the most truly brutal violence, sometimes, often, the experience of a more than desolate fragmentation.

It is not enough to know this. You have to live it. And learn to live with it. From his work on the iconography and literature of alchemy, Jung deepened his articulation of the confrontation with the shadow and spoke, in his language, of Zerstükelung, "smashing into pieces".

His acquaintance with the alchemists and their own modes of expression led him, in the last part of his work, to dramatise his thought, to concretely render it even closer to what he had learnt and could teach us. Once again, preceded by the alchemists, he anticipates many of the advances of contemporary psychoanalytical thought, notably Kleinian and Post-Kleinian, which also explore the truly frightening regions and modalities of our selves.

However, in the end everything is not really that dark. If Jung studies these manuals for so long and so attentively, it is because he also finds there a kind of silent knowledge, too enigmatic to be truly received, of strangely privileged pleasures, those that can be brought to life in the course of an analysis. 


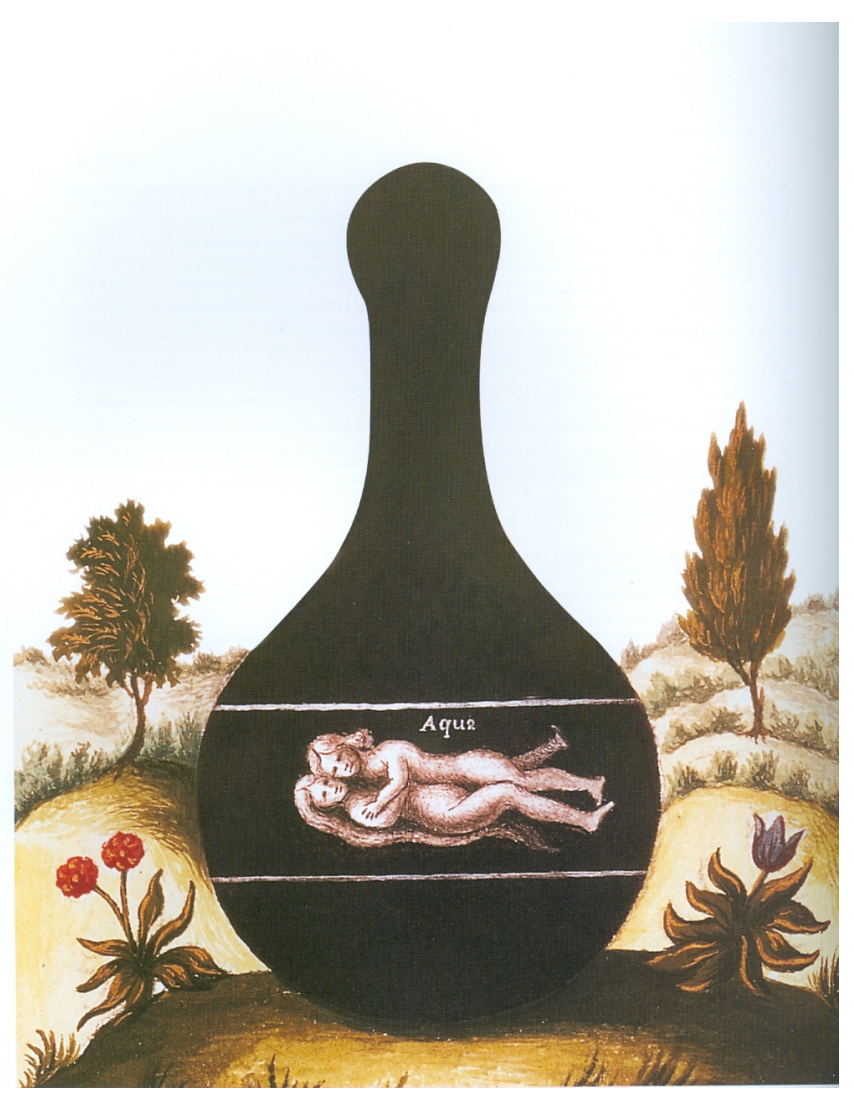

16. dans le bain

This engraving is to be found in the same alchemical manual as before. I shall not dwell on it, except to underline the proximity, the close understanding, the unveiled intimacy between the man and the woman in the safe hollow of their encounter.

This is one of the things that surprises the reader who follows Jung through his works. We discover that in the mid 1940s Jung wants to write a book about the new and modern practice of psychoanalysis, about its specificity and the necessary conditions for its success, and once again he illustrates his writings with the iconography and literature of the alchemists.

His book on transference, from 1946, uses the analysis of this engraving, and many others, and is nourished by them. For in this way he can better show and make understood the happy, warm, healing - and often unhoped-for - relationship that can be lived in the course of an analysis.

With the condition, of course, that the limits of such a relationship should be well defined and protective - and this is what this engraving already shows us, in its 
own way; today it can help us question the risks and regulations of our psychoanalytical practice.

\section{The modern era and contemporary creation}

At this point it would be necessary to dwell a little on Jung's relationship with the Art of the Modern era, and contemporary creation. But time is limited.

So I shall restrict myself to two examples.

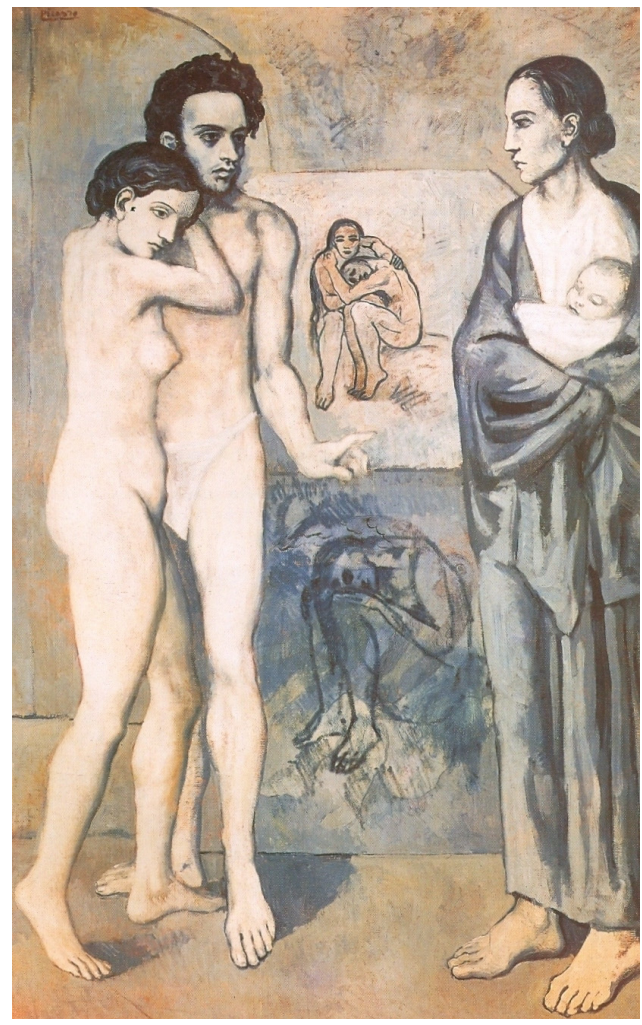

17. Picasso

In 1932 Jung dedicated an essay to the work of Picasso. This essay slightly precedes his first studies of alchemical iconography and literature. Jung wrote it on the occasion of a retrospective of Picasso's work organised by the Kunsthaus in Zurich.

When he discovers Picasso's work, Jung is first of all perplexed. Then he seems concerned. Because, in the year 1932, he notes that for a whole period the dominant colour of his paintings is blue. And this blue is truly a midnight blue. Night is threatening. And Jung thinks of the blue of Tuat, the Egyptian hell. 
What is more, these paintings portray very worrying figures. Firstly there is a woman, manifestly shattered, with her child in her arms. Or a young prostitute, apparently suffering from tuberculosis or syphilis. Then there are all sorts of fragments, splinters, collisions, until finally the tragic figure of Harlequin appears, himself fragmented and his costume made of pieces.

At this point Jung becomes truly afraid. What will become of Picasso if he goes this far in the company of figures and forms literally disarranged? He talks of a descent into Hell, like that which Homer, Goethe and Nietzsche and experienced. Of course he thinks also of the schizophrenics he knows only too well.

However, he emphasises that equally we must see the progressive staging of an antique and Dionysican joy, and the progressive deployment of the colours that for a long time were only to be found in the Harlequin's costume.

Jung, of course, remains concerned. And it must be said that what followed did not prove him wrong, since we know that Picasso was to live a long period of crisis and low productivity after 1932, and that he only overcame it by giving himself over to the series of engravings centred on the figure of the blind Minotaur.

In fact, as you will have understood, although Jung remains worried about the artist Picasso, his main attention is on the process engaged in his work. He sees things in perspective, and he follows their course, evaluating critical moments and asking himself what will come next. To the extent that I shall go as far as to say that the art is more important to him than the artists.

Another work of contemporary creation that marked Jung and both provoked and supported his analytical thinking was that of Yves Tanguy.

Pro-Posições, v. 21, n.2(62), maio/ago. 2010 


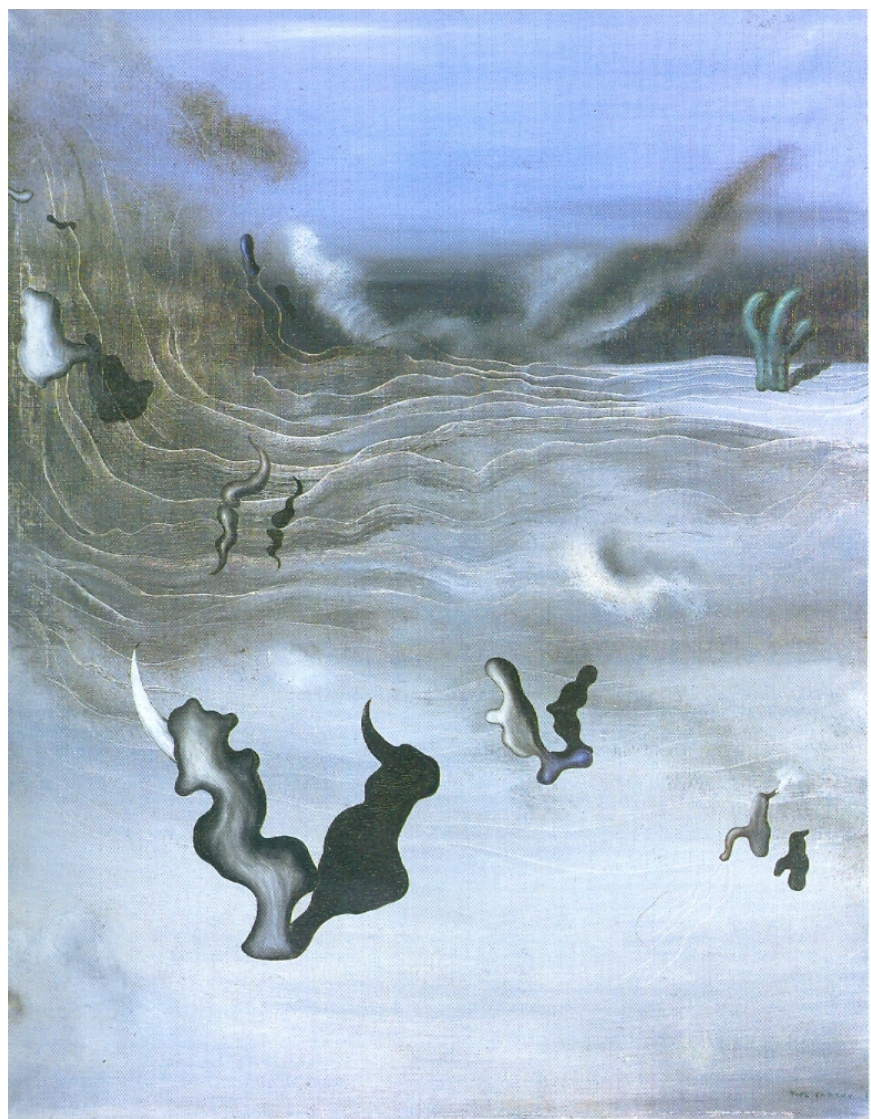

18. Yves Tanguy

This work turns up in Jung's writings rather unexpectedly. It appears in his essay - so often misunderstood - on "flying saucers", which he published at the end of the 1950s, just before his death.

Of course, Jung is not interested in discussing the existence or not of "flying saucers". His focus is elsewhere. He wants to explore the persistent and visionary rumour around this subject. The most important thing for him is the forms this rumour and these visions take: holes, circles, spherical shapes, and especially organic forms. We cannot really distinguish whether they are appearing or disappearing whether we are at the beginning or the end of time...

So he widens his enquiry, going further back in history, and he discovers this type of vision in engravings and narratives from the sixteenth century, and from the twelfth century too, notably in the writings of Hildegarde of Bingen, that is to say at particularly critical moments of our collective history. 
Tanguy's painting tends in this direction, with its inchoative forms that could be the beginning of something, or on the contrary only the remains of life, after destruction.

And Jung questions this disarray, and more radically still the distress that is manifested here, at the same time as he passionately observes the possible beginning of a new world that is seeking its own form in this way.

He observes destruction as a condition, and perhaps a cause, of beginning. And his attention is especially devoted to these structures that organise representation, and which are common to all of us because they are in fact transpersonal - these organising structures which he calls archetypes, and which we can see at work here more than ever, our arts that have been liberated from narration and figuration since the beginning of the twentieth century.

The work of Yves Tanguy led him to better adjust his thinking on this subject.

\section{In conclusion}

I said in the introduction that Jung's approach to the arts first consists in letting whatever presents itself come to him, letting these encounters happen, whether the creations are yesterday's or today's, whether they come from long ago, or from far away, or from cultures that are truly other, truly different from our own history.

And we have seen along this journey of large strides through Jung's work that this approach, rather than leading to yet another applied psychoanalysis, is built from encounters.

Encounters that interrupted and surprised him, then go on to nourish and revive his manner of being an analyst, and from there participate in the reworking and renewing of his thinking at each stage of its development.

It remains, when following Jung, to let oneself be impressed by that which presents and represents itself. By letting the emotion surface, of course, that mobilises both sentiment and sensation in the hollow and movement of the body when we are in front of a work of art. But also by observing at the same time, as precisely as possible, whatever is created here in this work.

This kind of observation, above all phenomenological, can progressively lead to an intelligence and a way of apprehending both the organising structures of representation and experience, and the processes involved in the arts, often at a scale quite beyond the individual.

Of course Jung could show his concern for the personal situation of an artist; we saw as much with Picasso. But this is not what is most decisively at stake in Art, if we follow Jung. Art is at the very least transgenerational, which is to say that it is closely connected with the progress, and regressions, of a culture through its longterm transformations, from one generation to another, at a timescale and rhythm often incomparable with those of one person's life. 
I can say, with and since Jung, that Art puts us in contact, physically and psychologically, with that which, often without us being aware of it, in fact surprises, occupies and preoccupies us, haunts, moves and agitates us, but which also animates us from the furthest point of ourselves. Because Art makes it visible, perceivable, liveable, thinkable.

But on condition that we really are really engaged with the encounter and the confrontation, if possible with our hands.

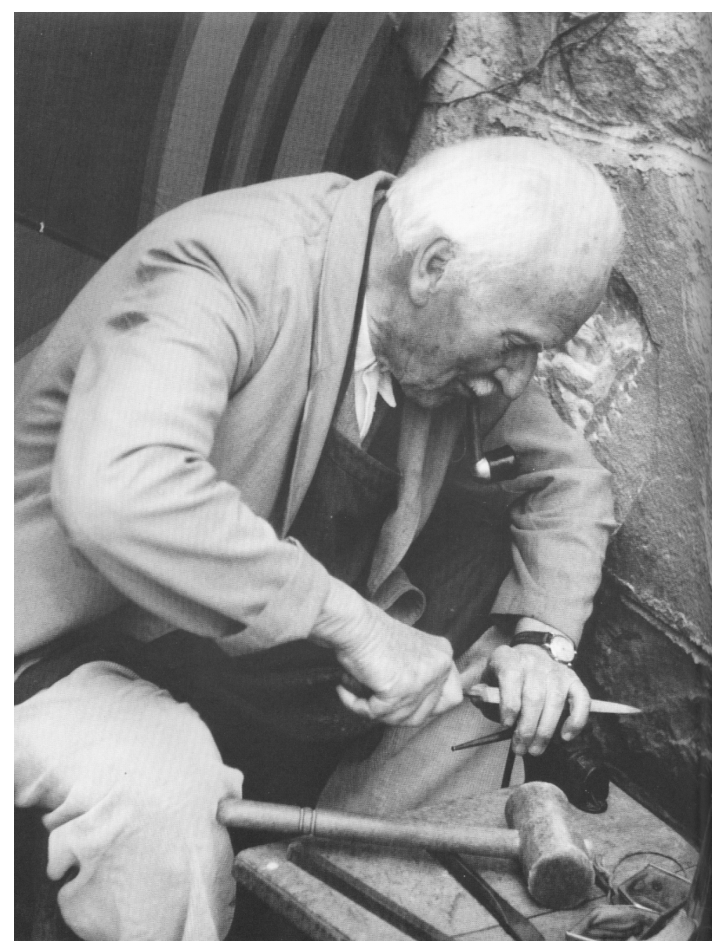

19. Jung en sculpteur

Here is Jung at work. Sculpting. He is in the courtyard of the house he had built, and which he partly built himself, on the shores of Lake Constance, where he liked to retire in the summer, often alone.

And here, to end with, is one of the sculptures he created here, and which is embedded into the wall of this house in the form of a tower.

Pro-Posições, v. 21, n.2(62), maio/ago. 2010 


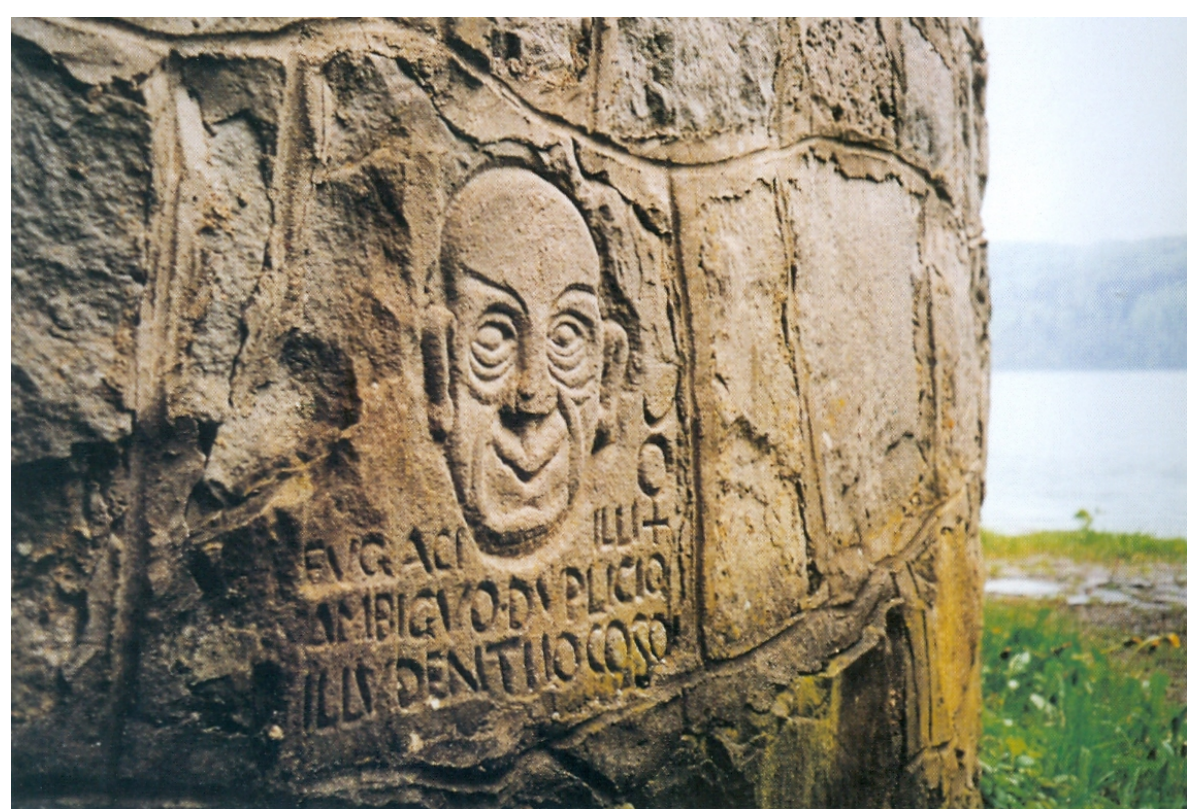

20. le trickster

It is a trickster who is manifestly watching him, and us, mockingly. I photographed it myself when I was visiting the house.

You know that a trickster, as its name shows, is a figure, a typical and archetypal character, who likes to watch us with an odd look, and who in fact never stops playing tricks on us.

Jung inscribed this figure into the wall of his house, in his "Tower", no doubt so as to always remember, and perhaps remind us, that whatever comes from our archaic depths, or our highest ideals, or from our ordinary surprises, can impress, impassion or frighten us, but that it is better not to lose sight of the fact that the unconscious also plays tricks on us, odd tricks - going as far, I fear, as to make fun of the heaviness of our approach, and no doubt more particularly of this presentation I have just made. 